\title{
Trends and Issues of the Coffee Industry of Ifugao: an Empirical Analysis
}

\author{
Jennifer Madonna G. Dait \\ Ifugao State University, Lagawe Campus, College of Business and Management, \\ Bahawit, Poblacion West, Lagawe, Ifugao 3600, Philippines
}

\begin{abstract}
This paper primarily aimed on analyzing the trends and issues affecting the coffee production in Ifugao. The study uses ordinary least squares regression to analyze sustainability variables: land area, number of bearing trees and average farm gate price against volume of production from 1990 to 2014. Subsequently, the researcher obtained significant results. It was found out that Land area, Farm gate price and Number of bearing trees were significant. It was also observed that average farm gate price had an indirect relationship with volume of production. This reflects that if average farm gate price increases, volume of production decelerates. These figures show that no established market exists yet for coffee in Ifugao. The proximity effect exhibited by the findings raises the need for economies of scale in dealing with the factors affecting volume of production of coffee in Ifugao. Efforts to strengthen regional trade and integration may be an important strategy to enhance the industry.
\end{abstract}

Keywords: coffee, land area, bearing trees, regression

\section{Introduction}

Coffee is the most traded commodity in the world market next to oil. Globally, coffee consumption is estimated at more than six million tons a year and retail sales mainly in Europe, USA and Japan are estimated to be US 70 billion dollars a year.

The coffee industry is considered as the biggest exports next to oil and is considered as a main crop of top exporting countries like Brazil, Mexico and even the US. Studies have also shown the profitability of the industry.

The Philippines is one of the few countries worldwide where the Arabica, Robusta, Excelsa and Liberica commercial coffee varieties are found. Likewise, the Cordillera Administrative Region (CAR) is one of the few regions in the country where the four varieties are grown.

Coffee growing is a province wide economic activity although three areas are particularly regarded as three coffee producing municipalities - Asipulo, Lagawe and Kiangan. The province of Ifugao has a total coffee production of 1120 metric tons (mt) of which $1105.56 \mathrm{mt}$ are of Robusta variety while $14.55 \mathrm{mt}$ are of Arabica variety. There are 1421 households involved in coffee production covering a total land area of 2520 hectares. Approximately, $0.42 \mathrm{mt}$ per hectare are planted with coffee trees. At present, there are 64 655 bearing trees and 22714 that are not yet bearing (DTI Ifugao, 2013). Majority of the beans are being sold to NESTLE Philippines - the world biggest food group for their preference to buy everything regardless of the coffee class.

Interviews with local folks of Ifugao attested the abundance of the coffee beans in the province and have been capitalized early on by most farmers. Dialogues with some personnel from BAS-Ifugao, DTI-Ifugao and the Provincial Agriculture and Environment \& Natural Resources (PAENRO-Ifugao) also attested the abundance of coffee beans in the province. Ms. Eleanor B. Saludares of DTI-Ifugao was even quoted by the researchers that sometime in 1994, NESCAFE
Philippines has seen the province's potentials as a coffee producer and has conducted seminars on coffee production at the Ifugao State College of Agriculture and Forestry (now IFSU). Productions though, in the 90's declined and accordingly, land areas for coffee were converted for production of other organically-grown crops (BAS-Ifugao). In the mid-1990s to early 2000s - farmers were also encouraged by the government (DENR) to plant Melina trees.

On previous surveys conducted by DTI-Ifugao, they were also able to identify issues and problems on the coffee industry of the province - among which are; limited supply of coffee beans and limited coffee nurseries, insufficient technical and entrepreneurial skills of growers, lack of access to the coffee industry market, and industry support and advocacy.

Given the importance of coffee production and processing in commodity development, and the refocusing on the Ifugao coffee to become one of the local commodities for comparative advantage as the One-Town-One-Product (OTOP) commodity, not to mention the province's inherent strengths - viz: ideal climate for year round production, capability to grow the commercial varieties of coffee beans, topography, land area, number of growers involved in the coffee industry and the province's geographical proximity and accessibility of roads to nearby provinces and key cities of Luzon; would henceforth give the province an edge in the domestic market.

Thus, the potential of the coffee industry of Ifugao, the numerous comparative economics studies on the topography and agricultural practicesof Ifugao and its' sister provinces like Benguet and Kalinga, and the common issues or problems determined earlier has interested the researcher to conduct a study on the aforementioned. Comparatively, Ifugao has far better resources and manpower to become a top domestic producer of coffee. To find out factors affecting the sustainability of the coffee industry of Ifugao - data on the volume of production of coffee in Ifugao from 1990 to 


\section{International Journal of Science and Research (IJSR) \\ ISSN (Online): 2319-7064}

Index Copernicus Value (2013): 6.14 | Impact Factor (2015): 6.391

2014 will be regressed against data on land area, farm gate price of coffee, and number of bearing trees.

Sustainability labels are important tools that help consumers assess the sustainability aspects of food (Van Loo, et al, 2015); however, no empirical studies on the sustainability indicators on the coffee industry have been revealed using distinctive decadal variability. It is therefore important to analyze the relationship among these variables of the sustainability indicators of the coffee industry to provide decision-makers with the needed information and tools to assess and boost the said industry.

This study aimed to analyze the effect of land area used in coffee production, number of coffee bearing trees and the average farm gate price of coffee in Ifugao to the Volume of Production of coffee in Ifugao covering the period of 1990-

2014.Specifically, it sought to answer the following:

1. What is the trend of volume of production of coffee in Ifugao from 1990 to 2014 ?

2. What is the trend of sustainability variables from 1990 to 2014 using:

2.1 Land area

2.2 Number of Bearing Trees

2.3 Average Farm Gate Price

3. What is the effect of the conditioning variables in Item 2 to the volume of production of coffee in Ifugao?

\section{Research Methodology}

To answer the main problem of this research, the descriptivecausal research was used as the research design of this study. The descriptive aspect dwells on the historical performance of the volume of production of the coffee industry of Ifugao, and on the conditioning variables that have been identified and cited in the previous pages of this paper. Supporting tables and graphs were supplied to highlight some of the early observations.

\section{The Empirical Model}

The economic model describing how agricultural output is affected by the identified predictor variables will follow a Cobb-Douglas form. The estimating equation is in logarithmic form as follows:

$\ln V O P=\beta 1+\beta 2 \ln L A+\beta 3 \ln F G P+\beta 4 \ln N B T+\varepsilon$

This is known as a Cobb-Douglas form of the production function widely used to represent the technological relationship between the amounts of two or more inputs, particularly physical capital and labor, and the amount of output that can be produced by those inputs.

\section{Results and Discussions}

This section presents the results, analysis and interpretation of data necessary in attaining the objectives of the paper.

\subsection{Trend of Volume of Production from 1990 to 2014.}

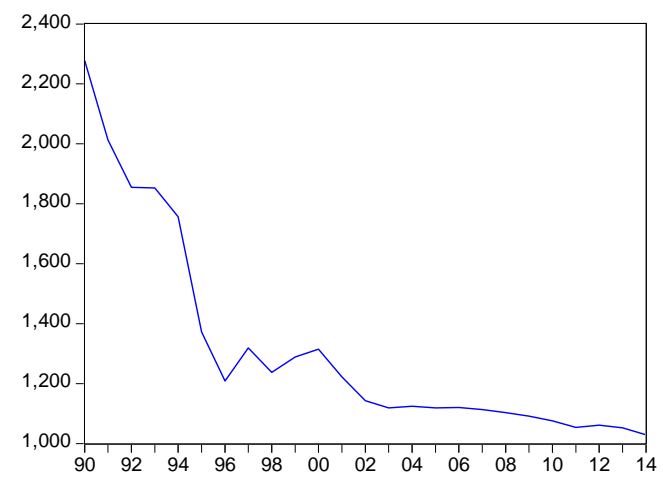

Figure 1: Volume of production of coffee in Ifugao from 1990-2014

Figure 1 shows the overall trend of volume of production of coffee in Ifugao for the period of 1990 to 2014. In 1990, figure shows the highest volume of production of coffee in Ifugao of 2277.47 metric tons, but there was a decline in production from 1991 to 1996 as most of the farmers shifted to planting organic crops. Although a shift of volume in 1997 until 2000 happened, production of coffee in Ifugao from 2001 to 2014 was still declining, despite of government programs like putting up a coffee board, to boost the industry (DTI-Ifugao, 2015).

\subsection{Trend of sustainability variables from 1990 to 2014 .}

\subsubsection{Land area}

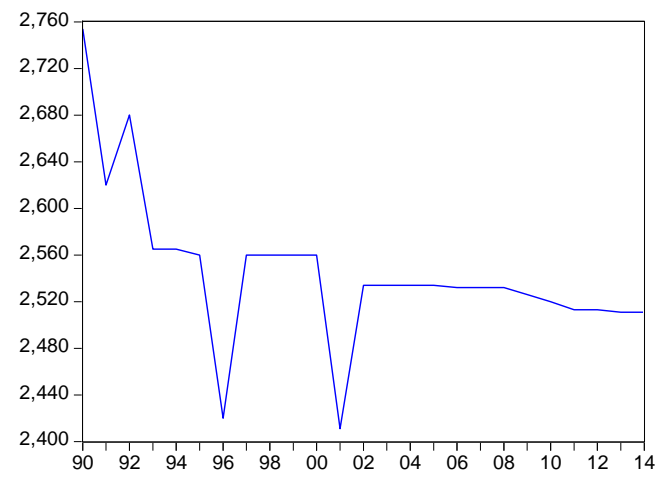

Figure 2: Land area used in coffee production from 19902014

Figure 2 shows the trend of land area used in the production of coffee in Ifugao from 1990 to 2014. In 1996 and 2001, land area ratio went down from 2560 hectares to 2420 hectares, and in 2001 - ratio went down from 2560 hectares to 2411 hectares. According to the Department of Trade and Industry (DTI) and Bureau of Agricultural Statistics (BAS) in Ifugao, land areas for coffee were converted for production of other organically grown crops because of the higher income they can get from selling this crops rather than coffee. In the mid-1990s to early 2000 s - farmers were also encouraged by the government (DENR) to plant Melina trees. 


\section{International Journal of Science and Research (IJSR) \\ ISSN (Online): 2319-7064}

Index Copernicus Value (2013): 6.14 | Impact Factor (2015): 6.391

\subsubsection{Number of Bearing Trees}

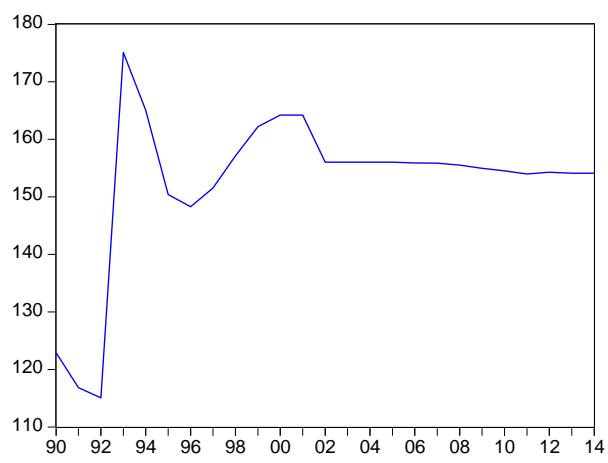

Figure 3: Number of coffee bearing trees from 1990-2014

Figure 3 presents the trend of number of coffee bearing trees in Ifugao from 1990 to 2014. As shown in the graph, the early 90s show erratic changes on the number of coffee bearing trees in Ifugao. The $29.8 \%$ increase of coffee bearing trees from 1990 to 1993 could account for the fact that coffee trees bear fruits 2-4 years after planting. After 2002, there was a slight decline on the number of bearing trees.

\subsubsection{Average Farm Gate Price}

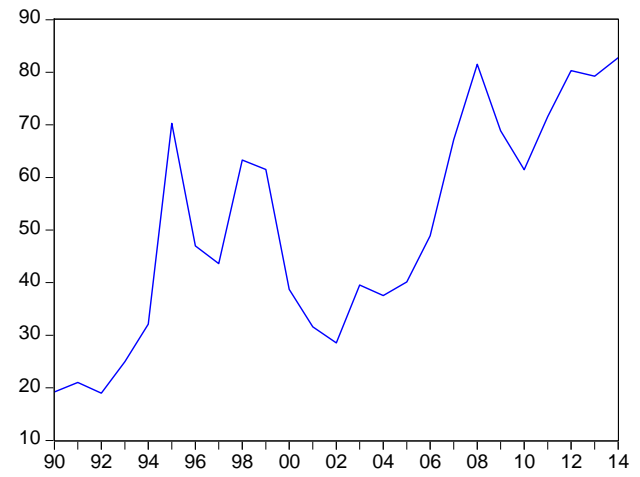

Figure 4: Volume of production of coffee in Ifugao from 1990-2014

Figure 4 reveals the trend of the average farm gate price per kilo of coffee in Ifugao from 1990 to 2014. Irregular patterns on the farm gate price of coffee canbe gleaned from the graph. According to DTI-Ifugao, there is no fixed market for the coffee, which could explain for the changes of price.

\subsection{Effect of sustainability variables to the volume of production of coffee in Ifugao from 1990 to 2014}

To achieve the objectives of this paper, the researcher used the multiple regression analysis in which the econometric model was used to determine which among the economic factors in the coffee industry in Ifugao significantly affect volume of production.

The original regression was tested for autocorrelation, heteroskedasticity, normality test and multicollinearity. This was to assure that any interference from the result would be valid.

Analyzing the distribution of errors, the researcher used the probability of Jarque-Bera. This gives the p-value of 0.13083 , which is greater than the level of significance of
0.05 . From this value, the researcher hypothesized to accept the null that errors are normally distributed. Meaning, there is normal distribution of errors.

To determine if the model has a presence of autocorrelation, the researcher made used of the Durbin-Watson Autocorrelation Test. Since the Durbin-Watson statistics show a statistics of 2.299764, the researcher accepted the null that no autocorrelation exist in the model.

To test for the presence of Heteroskedasticity the researcher made used of the White Heteroskedasticity test. The product of observed R-squared and the number of observation is 5.343220 and p-value is .4320 greater than the level of significance of $5 \%$. Therefore, the researcher does not reject the null hypothesis that heteroskedasticity exist in the model.

In addition, the researcher tested the presence of multicollinearity in the model using the correlation matrix. Summary of correlation matrix of volume of production of the coffee industry of Ifugao and the different indicators of the coffee industry of Ifugao is shown in the table below:

Table 1: Regression Results

\begin{tabular}{|c|c|c|c|c|}
\hline \multicolumn{5}{|c|}{ Dependent Variable: DVOP } \\
\hline \multicolumn{5}{|c|}{ Method: Least Squares } \\
\hline Sample (a & djusted): 199 & 22014 & & \\
\hline \multicolumn{5}{|c|}{ Included observations: 23 after adjustments } \\
\hline Variable & Coefficient & Std. Error & t-Statistic & Prob. \\
\hline $\mathrm{C}$ & -6.464837 & 3.326846 & -1.943233 & 0.0687 \\
\hline DFGP & -0.080728 & 0.030867 & -2.615344 & 0.0181 \\
\hline DLA & 1.425878 & 0.407197 & 3.501695 & 0.0027 \\
\hline DNBT & 0.515394 & 0.108516 & 4.749458 & 0.0002 \\
\hline $\mathrm{AR}(1)$ & 0.590663 & 0.213332 & 2.768755 & 0.0131 \\
\hline $\mathrm{AR}(2)$ & 0.180583 & 0.189041 & 0.955263 & 0.3528 \\
\hline R-squared & 0.965387 & \multicolumn{2}{|c|}{ Mean dependent var } & 7.110796 \\
\hline $\begin{array}{l}\text { Adjusted R- } \\
\text { squared }\end{array}$ & 0.955207 & \multicolumn{2}{|c|}{ S.D. dependent var } & 0.176224 \\
\hline $\begin{array}{c}\text { S.E. of } \\
\text { regression }\end{array}$ & 0.037297 & \multicolumn{2}{|c|}{ Akaike info criterion } & -3.520366 \\
\hline $\begin{array}{l}\text { Sum squared } \\
\text { resid }\end{array}$ & 0.023648 & \multicolumn{2}{|c|}{ Schwarz criterion } & -3.22415 \\
\hline \begin{tabular}{|l|} 
Log likelihood \\
\end{tabular} & 46.48421 & \multicolumn{2}{|c|}{ Hannan-Quinn criter. } & -3.445868 \\
\hline F-statistic & 94.82904 & \multicolumn{2}{|c|}{ Durbin-Watson stat } & 2.299764 \\
\hline $\begin{array}{l}\text { Prob(F- } \\
\text { statistic) }\end{array}$ & 0 & & & \\
\hline $\begin{array}{c}\text { Inverted AR } \\
\text { Roots }\end{array}$ & .81 & & -.22 & \\
\hline
\end{tabular}

Based on the table, the three independent variables: average farm gate price, total land area and number of bearing trees has low level of correlation. All of them have the value less than 0.80 , which signifies that multicollinearity is absent in the model.

The table showed that the coefficient of determination (Rsquared) was equal to 0.965387 which means that 96 percent of the variation in volume of production is explained by the different indicators of the coffee industry of Ifugao. The Pvalue of 0.000000 , which is less than 0.05 suggests that the model is highly significant. As to the standard error, the lower the Standard Error of regression, the higher it's precision. The standard error of regression is 0.037297 , which means the model is precise. 


\section{International Journal of Science and Research (IJSR) \\ ISSN (Online): 2319-7064}

Index Copernicus Value (2013): 6.14 | Impact Factor (2015): 6.391

Since the whole model is highly significant, the researcher analyzed and interpreted that volume of production is affected by changes in the different indicators in the coffee industry in Ifugao. Using the regression coefficient, the econometric model is:

$$
\begin{gathered}
\ln V O P=-6.464837+1.425878 L A-0.08728 F G P+ \\
0.515394 N B T+\varepsilon(2)
\end{gathered}
$$

On the analysis of regression, the independent variable LA manifested a t-stat equal to 3.501695 with P-value of 0.0027 less than 0.05 , hence total Land Area is highly significant. Total land area affects the volume of production of the coffee industry of Ifugao.

From the regression, FGP had a t-stat of -2.615344 , which has a P- value of 0.0181 less than the 0.05 level of significance, hence average Farm gate price is also highly significant. The value of its coefficient, 0.080728 , means that for every 1 peso increase in average farm gate price, there is a corresponding 0.080728 decrease in volume of production, taking into account the negative sign of the constant. It coincides with the socio-economic study of the Food and Agriculture Organization (FAO, 2000) that the negative relationship on production of agricultural products could be attributed to the fact that there is no existing market for the product. Similarly, a study by Erdal (2009) shows the same relationship of potato production and its price in Turkey.

To test the significance of Number of bearing trees, t-stat and p- value were also considered. T-stat of 4.749458, and pvalue of 0.0002 , means it is highly significant. It is also connotes that a one percent increases in NBT will lead to $6.464837 \%$ or about $600 \%$ increase in volume of production. Which, evidently shows that more fruit bearing trees, regardless of other factors, would naturally increase production. The same is true for the land area (LA) - a 1hectare increase in the utilization of land in the production of coffee would increase volume of production of coffee by $142.58 \%$.

\section{Recommendations}

1) To ensure a proactive engagement in increasing volume of production, enhancement of the coffee industry of Ifugao should be integrated into the province's development agenda and also reflected into budget implementation.

2) The proximity effect exhibited by the findings raises the need for economies of scale in dealing with the factors affecting volume of production of coffee in Ifugao. Efforts to strengthen regional trade and integration may be an important strategy to enhance the industry.

\section{References}

[1] Barham, BL, \& Weber, GJ 2012, 'The economic sustainability of certified coffee: Recent evidence from Mexico and Peru', World Development, vol 40, Issue 6, pp 1269-1279.

[2] Barham, Callenes, Lewis, Gitter, \& Weber, 2011a, 'The Economic Sustainability of Certified Coffee: Recent Evidence from Mexico and Peru', Vol. 40, No. 6, pp. 1269-1279
[3] Beuchelt, TD, \& Zeller, M 2011, 'Profits and poverty: Certification's troubled link for Nicaragua's organic and fairtrade coffee producers', Ecological Economics, vol 70, issue 7, pp 1316-1324.

[4] Bolwig S, Gibbon P, \& Jones S 2009, 'The economics of smallholder organic contract farming in tropical Africa', World Development, vol 37 issue 6, pp 1094 1104.

[5] Erdal, H, Erdal, G and Esengun, K 2009, 'An Analysis Of Production And Price Relationship For Potato In Turkey: A Distributed Lag Model Application', Bulgarian Journal of Agricultural Science, vol 15, issue no 3, pp 243-250.

[6] Giovannucci, D., Liu, P and Byers, A. 2008, 'The State of Sustainable Coffee: A Study of Twelve Major Markets. Emerging Issues', The North American Organic Coffee Industry Report, FAO, Rome.

[7] Gujarati, Damodar N., and Dawn C. Porter 2009, 'Basic econometrics. McGraw-Hill Irwin

[8] Jaffe, R. 2007, 'Confronting the coffee crisis: Fair trade, Sustainable livelihoods and ecosystems in Mexico and Central America', Massachusets Institute of Technology, USA.

[9] Pindyck, R. 2011, Microeconomics 7th edn, Harlow: Pearson Education

[10] Valkila, J. (2009). Fair Trade organic coffee production in Nicaragua - Sustainable development or a poverty trap?. Ecological Economics, 68(12), 3018-3025.

\section{Author Profile}

Jennifer Madonna G. Dait received her BS Economics and MBA degrees from St. Mary's University in 1998 and 2008, respectively. Recently, she finished her Master of Arts in Economics from the University of Sto. Tomas and currently taking up her $\mathrm{PhD}$ in Economics from the same University. She is currently employed with the Ifugao State University under the College of Business and Management. 